\title{
PENGARUH KREATIVITAS DAN MOTIVASI BELAJAR SISWA TERHADAP PRESTASI BELAJAR BAHASA ARAB DI MA DDI AL-BADAR
}

\author{
Muhammad Idris Usman \\ Sekolah Tinggi Agama Islam (STAI) DDI Parepare \\ Kampus Pontren DDI Lilbanat, Jl. Abu Bakar Lambogo No. 53 Soreang Parepare \\ Email: staiddi_pares@yahoo.co.id
}

\begin{abstract}
Abstrak:
Artikel ini merupakan hasil penelitian yang membahas tentang: 1) pengaruh antara kreativitas dengan prestasi belajar Bahasa Arab, 2) pengaruh antara motivasi belajar dengan prestasi belajar Bahasa Arab, 3) pengaruh antara kreativitas dan motivasi belajar dengan prestasi belajar Bahasa Arab siswa MA Al-Badar DDI Parepare. Pendekatan penelitian ini adalah kuantitatif dengan Metode korelasional. Populasi penelitian ini adalah seluruh siswa MA Al-Badar DDI Parepare yang berjumlah 112 orang dengan jumlah sampel 55 orang siswa. Instrumen yang digunakan angket (kuisioner). Analisis data dengan statistika deskriptif, statistika inferensial. Hasil penelitian menunjukkan 1) kreativitas dan motivasi belajar secara bersama-sama berpengaruh terhadap prestasi belajar siswa pada mata pelajaran Bahasa Arab, 2) Motivasi belajar berpengaruh positif terhadap prestasi belajar siswa pada mata pelajaran bahasa Arab, 3) motivasi belajar berpengaruh positif terhadap prestasi belajar siswa pada mata pelajaran bahasa Arab di Madrasah Aliyah (MA) Al-Badar DDI Parepare Sulawesi Selatan.
\end{abstract}

\begin{abstract}
:
This article is the result of the research which discuss about: 1). The influence of creativity toward students' Arabic achievement, 2). The influence of learning motivation toward students' Arabic achievement, 3 . The influence of creativity and learning motivation toward students' Arabic achievement at MA Al-Badar DDI Parepare. This research used quantitative approach with correlational design. The population of the research was all the students at MA Al-Badar DDI Parepare which consist of 112 with 55 samples. The instrument of research was questionnaire. Data were analysed by descriptive statistics and inferential statistic. The result of the research shows that 1) creativity has pocitive influence toward students' learning achievement in Arabic language; 2) motivation has positive influence toward leaning achievement at arabic language; 3) creativity together with motivation influence positively toward students achievement in Arabic language at MA Al-Badar DDI Parepare.
\end{abstract}

Kata kunci:

Kreativitas, Motivasi, Prestasi, Belajar

MADRASAH adalah merupakan lembaga yang mengkhususkan diri untuk kegiatan pendidikan Islam, tempat masyarakat mentransfer keterampilan, kebiasaan, cita-cita dan pengetahuan dari suatu generasi ke generasi yang lain. ${ }^{1}$ yang merupakan tujuan dan inti dari pelajaran bahasa Arab pada pembelajaran bahasa Arab di Madrasah Aliyah (MA) Al-Badar DDI Parepare. 
Madrasah Aliyah (MA) Al-Badar DDI Parepare adalah lembaga pendidikan menengah sebagaimana tercantum dalam Undang-undang Republik Indonesia nomor 20 tahun 2003 tentang Sistem Pendidikan Nasional (Sisdiknas) pasal 18 ayat 2 sebagai berikut: Pendidikan menengah terdiri atas pendidikan menengah umum dan pendidikan menengah kejuruan. Pada ayat 3 disebutkan bahwa pendidikan menengah berbentuk sekolah menengah atas (SMA), madrasah aliyah (MA), sekolah menengah kejuruan (SMK), dan madrasah aliyah kejuruan (MAK), atau bentuk lain yang sederajat (Undang-undang Sisdiknas No. 2 tahun 2003).

Jadi pada dasarnya sudah tidak ada perbedaan status antara Sekolah Menengah Atas (SMA), Sekolah Menengah Kejuruan (SMK), Madrasah Aliyah Kejuruan (MAK) atau Madrasah Aliyah (MA). Semua memiliki kesempatan dan peluang yang sama untuk mengembangkan dan memajukan lembaga pendidikannya masing-masing.

MA Al-Badar DDI Parepare adalah tempat peneliti akan melakukan penelitian. Penentuan tempat penelitian ini dengan pertimbangan bahwa terdapat masalah di bidang akademik siswa dan juga pertimbangan dari segi kepraktisan dimana peneliti berdomisili di Kota Parepare sehingga mudah dalam pelaksanaan penelitian. Peneliti melakukan penelitian juga dalam upaya perbaikan daerah sendiri agar lebih baik di bidang pendidikan.

Mengacu pada hal tersebut, maka penelitian ini dilakukan untuk mengetahui faktor-faktor yang menyebabkan masih rendahnya prestasi belajar Bahasa Arab siswa. Berdasarkan hasil observasi di SMA Al-Badar DDI Parepare siswa masih mengalami kesulitan atau lamban dalam menangkap pelajaran Bahasa Arab. Terdapat siswa yang gelisah di kelas kemudian bertanya pada teman sebangkunya ketika guru memberi materi pelajaran secara lisan. Siswa tersebut meminta temannya untuk menerangkan kembali penjelasan guru. Terdapat pula siswa yang meminta guru untuk menuliskan contoh soal dan jawabannya di papan tulis dan juga terdapat siswa yang diam saja tapi ketika ditanya guru, siswa tersebut tidak dapat menjawab.

Diperoleh pula melalui observasi, terdapat banyak siswa dalam menyelesaikan permasalahan bahasa Arab hanya mengerjakan seperti apa yang diberikan oleh guru mereka. Hal ini terlihat ketika mereka mengerjakan soal di papan tulis. Ketika permasalahan yang dihadapinya agak berbeda penyajiannya mereka merasa kesulitan untuk menyelesaikannya. Selain itu, cara penyelesaian permasalahan bahasa Arab setiap siswa terlihat homogen dan tidak ada yang mengerjakan soal dengan cara penyelesaian selain yang diajarkan guru karena takut salah. Hal ini dikarenakan cara berpikir mereka yang masih bersifat konvergen.

Oleh sebab itu, diperlukan kemampuan berkreativitas sehingga siswa dapat memilih dan menerapkan cara/metode yang tepat guna menyelesaikan permasalahan yang dihadapinya dengan benar. Pada akhirnya prestasi belajar diharapkan dapat optimal. Ada beberapa faktor yang mempengaruhi tinggi dan rendahnya prestasi belajar siswa, termasuk di dalamnya faktor intern dan faktor ekstern. Faktor-faktor tersebut sering kali menjadi penghambat dan pendukung keberhasilan siswa. Kreativitas dan motivasi belajar merupakan faktor intern yang terdapat dalam diri siswa yang dapat mendukung dan dapat juga menghambat prestasi belajar Bahasa Arab. 
Kreativitas dan motivasi belajar yang dipilih sebagai variabel yang diteliti, hal ini dikarenakan objek kajian yang dipelajari dalam Bahasa Arab bersifat abstrak (fakta, konsep, operasi, prinsip), terdapat pemecahan masalah, serta adanya pengertian yang masih lemah dan belum bermakna dalam memahami konsep bahasa Arab. Sehingga siswa masih kesulitan dalam mempelajari Bahasa Arab.

Pembelajaran bahasa Arab dapat mengembangkan keterampilan peserta didik dalam berkomunikasi lisan dan tulisan untuk memahami dan menyampaikan informasi, pikiran dan perasaan. Jadi, mata pelajaran Bahasa Arab diperlukan agar peserta didik dapat mengembangkan dirinya menjadi warga negara yang cerdas, terampil dan berkepribadian Indonesia, dapat mengembangkan ilmu pengetahuan.

Terdapat penelitian pendidikan yang mendukung penelitian yang akan dilakukan peneliti, diantaranya yaitu penelitian yang dilakukan Devi menunjukkan bahwa terdapat pengaruh antara motivasi belajar dengan prestasi belajar Bahasa Arab. ${ }^{2}$

Di lain pihak, penelitian Eni menunjukan bahwa kreativitas berpengaruh positif terhadap prestasi belajar Bahasa Arab. Keterkaitan antara kreativitas dan motivasi belajar dengan prestasi belajar Bahasa Arab ini juga didukung penelitian Sternberg yang mengungkapkan bahwa kreativitas berkaitan erat dengan intelegensi, gaya kognitif, dan kepribadian atau motivasi. ${ }^{3}$

Dengan demikian, dalam penelitian ini diharapkan mampu mengungkapkan hubungan antara kreativitas dan motivasi belajar siswa terhadap prestasi belajar Bahasa Arab untuk ketiga sekolah tersebut. Hal ini dimaksudkan guna memperoleh informasi mengenai kreativitas dan motivasi belajar dalam hubungannya terhadap prestasi belajar Bahasa Arab.

Berdasarkan latar belakang dapat dirumuskan permasalahan terseb ut sebagai berikut:

1. Adakah pengaruh kreativitas terhadap prestasi belajar Bahasa Arab MA Al-Badar DDI Parepare?

2. Adakah pengaruh motivasi belajar siswa terhadap prestasi belajar Bahasa Arab siswa MA Al-Badar DDI Parepare?

3. Adakah pengaruh kreativitas dan motivasi belajar terhadap prestasi belajar Bahasa Arab siswa MA Al-Badar DDI Parepare?

\section{KAJIAN TEORETIK}

\section{Prestasi Belajar Bahasa Arab}

Menurut Hilgard dan Bower yang dikutip oleh M. Ngalim Purwanto mengemukakan pengertian belajar sebagai berikut:

Belajar berhubungan dengan perubahan tingkah laku seseorang terhadap sesuatu situasi tertentu yang disebabkan oleh pengalaman yang berulangulang dalam situasi itu, dimana perubahan tingkah laku tidak dapat dijelaskan atau dasar kecenderungan respon pembawaan, kematangan, atau keadaan-keadaan sesaat seseorang (misalnya kelelahan, pengaruh obat, dan lain-lain. ${ }^{4}$ 
Sedangkan Slameto menyatakan bahwa belajar ialah suatu proses usaha yang dilakukan untuk memperoleh suatu perubahan tingkah laku yang baru secara keseluruhan, sebagai hasil pengalamannya sendiri dalam interaksinya dengan lingkungannya. ${ }^{5}$

Dua pendapat ahli tersebut, menunjukkan bahwa belajar dapat diartikan sebagai proses yang menghasilkan perubahan yang bersifat menetap dan menyeluruh sebagai hasil dari adanya respon individu terhadap situasi tertentu, namun juga berwujud keterampilan, kecakapan, sikap, tingkah laku, pola pikir, kepribadian, dan lain-lain.

Hasil belajar berasal dari bahasa Belanda "prestatie", dalam bahasa Indonesia menjadi prestasi yang berarti hasil usaha. Dalam literatur, prestasi selalu dihubungkan dengan aktivitas tertentu, seperti dikemukakan oleh Robert M. Gagne dalam artikel oleh Abu Muhammad Ibnu Abdullah bahwa dalam setiap proses akan selalu terdapat hasil nyata yang dapat diukur dan dinyatakan sebagai hasil belajar (achievement) seseorang. ${ }^{6}$

Muhibbin Syah menjelaskan bahwa: Prestasi belajar merupakan taraf keberhasilan sebuah proses mengajar-belajar (the teaching-learning process) atau taraf keberhasilan sebuah program pembelajaran/penyajian materi, dan kenaikan kelas. ${ }^{7}$

Berdasarkan pengertian di atas, maka dapat disimpulkan bahwa prestasi belajar merupakan taraf keberhasilan sebuah proses pembelajaran (the teaching-learning process) yang dicapai oleh seseorang setelah melakukan kegiatan belajar dan dinyatakan dalam raport. Prestasi belajar ditunjukkan dengan skor atau angka yang menunjukkan nilai-nilai darisejumlah mata pelajaran yang menggambarkan pengetahuan dan ketrampilan yang diperoleh siswa, serta untuk dapat memperoleh nilai digunakan tes terhadap mata pelajaran terlebih dahulu. Hasil tes inilah yang menunjukkan keadaan tinggi rendahnya prestasi yang dicapai oleh siswa.

\section{Kreativitas}

Pada hakikatnya perkataan kreatif adalah penemuan sesuatu yang baru, dan bukan akumulasi dari keterampilan atau pengetahuan yang diperoleh dari buku pelajaran. Kreatif diartikan juga sebagai pola berpikir atau ide yang timbul secara spontan dan imajinatif, yang mencerminkan hasil-hasil ilmiah, penemuan ilmiah, dan penciptaan-penciptaan secara mekanik.

Menurut Winkel, dalam kreativitas berpikir atau berpikir kreatif, kreativitas merupakan tindakan berpikir yang menghasilkan gagasan kreatif atau cara berpikir yang baru, asli, independen, dan imajinatif. Kreativitas dipandang sebuah proses mental. Daya kreativitas menunjuk pada kemampuan berpikir yang lebih orisinal dibanding dengan kebanyakan orang lain. ${ }^{8}$

Menurut Elizabeth Hurlock (seorang pakar psikologi perkembangan anak), kreativitas adalah kemampuan seseorang untuk menghasilkan komposisi, produk, atau gagasan apa saja yang pada dasarnya baru dan sebelumnya tidak dikenal pembuatnya. Ia dapat berupa kegiatan imajinatif atau sintesis pemikiran yang hasilnya bukan perangkuman. Ia mungkin mencakup pembentukan pola baru dan gabungan infor- 
masi yang diperoleh dari pengalaman sebelumnya dan pencangkokkan hubungan lama ke situasi baru dan mungkin mencakup pembentukan korelasi baru. Ia harus mempunyai maksud atau tujuan, bukan fantasi semata, walaupun merupakan hasil yang sempurna lengkap. Ia mungkin dapat berbentuk produk seni, kesusasteraan, produk ilmiah, atau mungkin bersifat prosedural atau metodologis. ${ }^{9}$

Menurut Buchori Alma, kreativitas adalah kemampuan seseorang untuk melahirkan sesuatu yang baru, baik berupa gagasan maupun karya nyata, yang relatif berbeda dengan apa yang telah dihasilkan maupun telah disampaikan. ${ }^{10}$

Dari beberapa definisi di atas disimpulkan bahwa kreativitas adalah tindakan berpikir yang imajinatif melalui proses mental dari keinginan yang besar dan disertai komitmen yang menghasilkan gagasan-gagasan baru, bersifat asli, independen, dan bernilai.

\section{Motivasi Belajar}

Setiap tindakan individu tidak pernah berdiri sendiri sendiri, selalu ada yang mendorongnya untuk mencapai sesuatu yang ingin dicapai. Sesuatu yang menjadi pendorong timbulnya tindakan individu disebut motivasi.

Dalam kamus besar bahasa Indonesia, motivasi di definisikan sebagai dorongan yang timbul pada diri seseorang secara sadar atau tidak sadar untuk melakukan suatu tindakan dengan tujuan tertentu. ${ }^{11}$ Sedangkan.menurut Sukmadinata, motivasi adalah kekuatan yang menjadi pendorong kegiatan individu. Kekuatan yang dimaksudkan disini adalah suatu kondisi dalam diri individu yang mendorong atau menggerakkan individu tersebut melakukan sesuatu. ${ }^{12}$

Berdasarkan kedua definisi di atas, dapat disimpulkan bahwa motivasi merupakan kekuatan yang menjadi pendorong individu untk melakukan kegiatan dalam rangka mencapai suatu tujuan.

Motivasi terbentuk dari tenaga yang bersumber dari dalam dan luar diri individu. Tenaga yang bersumber dari dalam diri individu disebut motivasi intern, dan tenaga yang bersumber dari luar individu disebut motivasi ekstern. ${ }^{13}$

\section{METODOLOGI PENELITIAN}

\section{Pendekatan dan Jenis Penelitian}

Pendekatan atau paradigma penelitian ini adalah paradigma kuantitatif. etode Metode yang digunakan dalam penelitian ini adalah penelitian korelasional yaitu metode penelitian yang mengkaji hubungan antara satu atau lebih variabel. Sedangkan analisis data yang digunakan adalah analisis data statistik inferensial dengan menggunakan rumus Multiple Linier Regression (Regresi Linier Berganda). Analisis ini bertujuan untuk mencari pola hubungan yang dapat digambarkan secara matematis antara satu variabel tak bebas $(\mathrm{Y})$ dengan dua variabel bebas yaitu $\mathrm{X}_{1}$ dan $\mathrm{X}_{2}$.

\section{Populasi dan Sampel Penelitian}

Populasi dalam penelitian ini adalah seluruh siswa MA Al-Badar DDI Parepare yang berjumlah 112 orang. 
Jumlah sampel yang diteliti sebanyak 50\% dari jumlah populasi sehingga diperoleh jumlah sampel sebesar 55 orang siswa. Adapun teknik yang dipergunakan dalam penentuan sampel adalah teknik random sampling, yaitu pengambilan sampel penelitian secara acak.

\section{Teknik/Jenis Pengumpulan Data}

Dalam penelitian ini peneliti menggunakan instrumen angket (kuisioner) dengan jumlah pernyataan pada variabel kreativitas (X1) ini sebanyak 12 dengan dimensi kecenderungan bersikap (fungsi perasaan) berjumlah 12 pernyataan. Sementara untuk variabel motivasi belajar (X2) menggunakan jenis instrumen menggunakan angket (kuisioner) dengan jumlah pernyataan pada variabel ini sebanyak 22 dengan rincian: untuk motivasi instrinsik berjumlah 6 dan untuk motivasi ekstrinsik berjumlah 16 pernyataan.

Data skor diambil dengan instrumen berbentuk pernyataan. Oleh karenanya instrumen pengukuran penelitian berbentuk skala. Data skor variabel kreativitas (X1) dan variabel Motivasi Belajar $\left(\mathrm{X}_{2}\right)$ diambil dengan instrumen berupa angket yang menggunakan skala Likert

Selanjutnya bentuk pernyataan dalam Skala Likert ini nilainya adalah positif dan negatif. Pernyataan positif mengharapkan responden memberikan jawaban positif sedangkan pernyataan negatif mengharapakan reasponden memberikan jawaban negatif.

\section{Teknik Analisis Data}

Analisis data yang dilakukan dalam penelitian ini meliputi analisis data dengan statistika deskriptif, analisis data dengan statistika inferensial dan uji persyaratan analisisnya. Analisis data dengan statistika deskriptif disajikan dalam bentuk tabel distribusi frekuensi dan histogram. Analisis data dengan statistika inferensial menggunakan Multiple Linier Regression (Regresi Linier Berganda) yang bertujuan untuk mencari pola hubungan yang dapat digambarkan secara matematis antara satu variabel tak bebas $(\mathrm{Y})$ dengan dua variabel bebas yaitu $\mathrm{X}_{1}$ dan $\mathrm{X}_{2}$. Sesuai dengan model analisis yang digunakan yaitu regresi linier berganda, maka uji persyaratan analisis yang dilakukan meliputi uji normalitas residual, uji homogenitas varians dan Uji multikolinieritas.

Pengujian kenormalan residual menggunakan Uji Kolmogorov-Smirnov (KS), uji homogenitas varians menggunakan Scatter plot antara SRESID (standardized residual) dan ZPRED (standardized predicted value). sedangkan Uji multikolinieritas menggunakan perbandingan nilai Variance Inflation Factor (VIF).

\section{Hipotesis Statistika}

Sesuai dengan banyaknya hipotesis penelitian yang telah diajukan, maka hipotesis statistik yang disajikan adalah sebagai berikut:

1. Hipotesis pertama

$$
\begin{aligned}
& \mathrm{H}_{0}: \beta_{12} \leq 0 \\
& \mathrm{H}_{1}: \beta_{12}>0
\end{aligned}
$$


2. Hipotesis Kedua

$\mathrm{H}_{0}: \beta_{2} \leq 0$

$\mathrm{H}_{1}: \beta_{2}>0$

3. Hipotesis Ketiga

$\mathrm{H}_{0}: \beta_{1} \leq 0$

$\mathrm{H}_{1}: \beta_{1}>0$

\section{HASIL PENELITIAN DAN PEMBAHASAN}

\section{Deskripsi Data}

Variabel prestasi belajar ( $Y$ ) memiliki rentang $X>66,7$ untuk kategori tinggi, 33,3 $\leq X \leq 66,7$ untuk kategori sedang, $X<33,3$ untuk kategori rendah. Berdasarkan kategorisasi memperlihatkan bahwa prestasi belajar (Y) adalah 76,4\% untuk kategori tinggi, 23,6\% untuk kategori sedang dan 0\% untuk kategori rendah. Hasil tersebut memperlihatkan bahwa secara keseluruhan prestasi belajar pada responden penelitian termasuk kategori tinggi. Lebih jelasnya dapat dilihat pada Tabel 1 berikut ini:

Tabel 1. Kategori Skor Variabel Prestasi Belajar (Y)

\begin{tabular}{|c|c|c|c|}
\hline Kategori & Skor & Jumlah & Prosentase \\
\hline \hline Tinggi & $X>66,7$ & 42 & $76,4 \%$ \\
\hline Sedang & $33,3 \leq X \leq 66,7$ & 13 & $23,6 \%$ \\
\hline Rendah & $X<33,3$ & 0 & $0 \%$ \\
\hline
\end{tabular}

Variabel kreativitas $\left(X_{1}\right)$ memiliki rentang $X>43,7$ untuk kategori tinggi, 28,3 $\leq$ $X \leq 43,7$ untuk kategori sedang, $X<28,3$ untuk kategori rendah. Berdasarkan kategorisasi memperlihatkan bahwa kreativitas $\left(X_{1}\right)$ obyek penelitian adalah $42 \%$ untuk kategori tinggi, 56\% untuk kategori sedang dan 2\% untuk kategori rendah. Hasil tersebut memperlihatkan bahwa secara umum pemahaman kreativitas responden termasuk kategori sedang. Lebih jelasnya dapat dilihat pada Tabel 2 berikut ini:

Tabel 2. Kategori Skor Variabel Kreativitas $\left(\mathrm{X}_{1}\right)$

\begin{tabular}{|c|c|c|c|}
\hline \hline Kategori & Skor & Jumlah & Prosentase \\
\hline \hline Tinggi & $X>43,7$ & 23 & $42 \%$ \\
\hline Sedang & $28,3 \leq X \leq 43,7$ & 31 & $56 \%$ \\
\hline Rendah & $X<28,3$ & 1 & $2 \%$ \\
\hline
\end{tabular}

Variabel persepsi motivasi belajar $\left(X_{2}\right)$ memiliki rentang $X>80,7$ untuk kategori tinggi, 51,3 $\leq X \leq 80,7$ untuk kategori sedang, $X<51,3$ untuk kategori rendah. Berdasarkan kategorisasi memperlihatkan bahwa kreativitas $\left(\mathrm{X}_{1}\right)$ obyek penelitian adalah 9\% untuk kategori tinggi, 87\% untuk kategori sedang dan $4 \%$ untuk kategori rendah. Hasil tersebut memperlihatkan bahwa secara umum persepsi motivasi belajar pada 
responden termasuk kategori sedang. Lebih jelasnya dapat dilihat pada Tabel 3 berikut ini:

Tabel 3. Kategori Skor Variabel Motivasi belajar $\left(\mathrm{X}_{2}\right)$

\begin{tabular}{|c|c|c|c|}
\hline Kategori & Skor & Jumlah & Prosentase \\
\hline \hline Tinggi & $\mathrm{X}>80,7$ & 5 & $9 \%$ \\
\hline Sedang & $51,3 \leq \mathrm{X} \leq 80,7$ & 48 & $87 \%$ \\
\hline Rendah & $\mathrm{X}<51,3$ & 2 & $4 \%$ \\
\hline
\end{tabular}

Berdasarkan hasil kategorisasi-kategorisasi yang telah dipaparkan terlihat bahwa kecenderungan prestasi belajar secara umum tergolong sedang. Hal ini dapat dinyatakan bahwa keberhasilan siswa dalam pendidikannya juga dipengaruhi kreativitas dan motivasi belajar yang dimiliki. Kreativitas dan motivasi sebagai daya dorong yang memungkinkan seseorang berhasil mencapai apa yang diidamkan termasuk prestasi belajar siswa Madrasah Aliyah (MA) Al-Badar DDI Parepare.

\section{Pengujian Persyaratan Analisis Data}

Untuk memastikan bahwa variabel-variabel yang diteliti dapat dianalisis dengan korelasi dan regresi berganda, harus memenuhi beberapa persyaratan uji analisis sebagai berikut:

\section{Uji Normalitas Residual}

Salah satu pengujian dalam model regresi yaitu apakah residual dari model berdistribusi normal atau dapat dinyatakan sebagai: $\varepsilon_{i} \sim N\left(0, \sigma^{2}\right)$. Pengujian kenormalan menggunakan Uji Kolmogorov-Smirnov (KS). Hipotesisnya dituliskan sebagai:

$\mathrm{H}_{0}=$ Residual berdistribusi normal

$\mathrm{H}_{1}=$ Residual tidak berdistribusi normal

\section{Uji Normalitas residual regresi $Y$ atas $X 1$}

Dari hasil pengujian menggunakan uji Kolmogorov-Smirnov menunjukkan bahwa nilai $P_{\text {value }}=0,491$ atau lebih besar dari $\alpha=0,05$, sehingga dapat disimpulkan bahwa residualnya berdistribusi normal.

\section{Uji Normalitas residual regresi $Y$ atas $X 2$}

Dari hasil pengujian menggunakan uji Kolmogorov-Smirnov, menunjukkan bahwa nilai $P_{\text {value }}=0,371$ atau lebih besar dari $a=0,05$, sehingga dapat disimpulkan bahwa residualnya berdistribusi normal.

\section{Pengujian Homogenitas Varian}

Pengujian persyaratan analisis selanjutnya adalah uji homogenitas varian. Uji homogenitas varian adalah menguji apakah varians dari residual tersebut konstan, atau varians dari setiap residual yang dihasilkan adalah tetap dan menyebar secara acak. Pemeriksaan ini dilakukan dengan metode grafik. Apabila plot antara ZRESID 
(standardized residual) dengan ZPRED (standardized predicted value) tidak menunjukkan suatu pola tertentu maka dikatakan residualnya memenuhi asumsi identik.

Dari hasil Scatter plot antara ZRESID (standardized residual) dan ZPRED (standardized predicted value) tidak membentuk suatu pola tertentu sehingga dianggap residual mempunyai homogen varians.

\section{Pengujian Multikolinieritas}

Uji multikolinieritas adalah pengujian untuk mengetahui ada atau tidaknya korelasi yang signifikan antar variabel bebas. Model regresi yang baik memiliki variabel-variabel bebas yang saling independen. Statistik uji yang sering dipergunakan untuk menguji gangguan multikolinieritas adalah dengan Variance Inflation Factor (VIF).

Dari hasil pengujian multikolinieritas, menunjukkan bahwa nilai VIF $=1,064$ atau lebih kecil dari 10 dan nilai $P_{\text {value }}=0,000$ atau lebih besar dari $\alpha=0,05$, yang keduanya menunjukkan bahwa tidak terdapat multikolinieritas antar variabel independen.

\section{Pengujian Hipotesis}

Untuk menguji hipotesis dalam penelitian ini digunakan teknik analisa data yaitu analisis linear berganda (multiple linier regression). Langkah-langkah perhitungan dalam analisis dinyatakan sebagai berikut:

\section{Menentukan Persamaan Regresi Berganda Y atas $X_{1}$ Dan $X_{2}$}

Untuk menentukan persamaan regresi berganda $Y$ atas $X_{1}$ dan $X_{2}$, maka data hasil penelitian sebagaimana yang disajikan pada lampiran 4 kemudian diolah dengan menggunakan software SPSS 16.0. Dari hasil pengolahan data dengan menggunakan software SPSS 16.0, maka persamaan regresi berganda $Y$ atas $X_{1}$ dan $X_{2}$ dapat dituliskan sebagi berikut:

$$
Y=55,667+0,201 X_{1}+0,226 X_{2}
$$

\section{Uji Signifikasi Persamaan Regresi Ganda Y atas X1 Dan X2}

Uji signifikasi persamaan regresi ganda $\mathrm{Y}$ atas $\mathrm{X} 1$ dan $\mathrm{X} 2$ dilakukan untuk menguji hipotesis statistik pertama yaitu:

$\mathrm{H}_{0}: \beta_{1}-\beta_{2}=0$

$\mathrm{H}_{1}: \beta_{1}-\beta_{2} \neq 0$

Hasil pengolahan data dengan menggunakan software SPSS 16.0, terlihat bahwa nilai signifikansi $F_{\text {hit }}\left(P_{\text {value }}\right)=0,000$ atau lebih besar dari $\alpha=0,05$, sehingga dapat disimpulkan bahwa variabel Kreativitas $\left(X_{1}\right)$ dan Motivasi Belajar $\left(X_{2}\right)$ secara bersama-sama (simultan) berpengaruh terhadap Prestasi Belajar $(Y)$.

\section{Uji Signifikasi Koefisien Korelasi Ganda Y atas X1 Dan X2}

Uji signifikasi koefisien korelasi ganda $\mathrm{Y}$ atas $\mathrm{X} 1$ dan $\mathrm{X} 2$ atau koefisien determinasi pada regresi linear berganda dimaksudkan untuk mengukur seberapa besar kemampuan semua variabel bebas $(X)$ dalam menjelaskan varians dari variabel terikatnya (Y). Pengujian tersebut dilakukan dengan menggunakan software SPSS 17.0. 
Hasil pengolahan data dengan menggunakan software SPSS 16.0, terlihat bahwa nilai $R$ Square yang diperoleh $=0,437$. Hal ini menunjukkan bahwa pengaruh variabel kreativitas $\left(\mathrm{X}_{1}\right)$ dan motivasi belajar $(\mathrm{X} 2)$ terhadap variabel prestasi belajar $(\mathrm{Y})$ adalah sebesar 0,437 atau $43,7 \%$.

\section{Uji Signifikasi Koefisien Persamaan Regresi Ganda Y atas X1 Dan X2}

Uji signifikasi koefisien persamaan regresi ganda $\mathrm{Y}$ atas $\mathrm{X} 1$ dan $\mathrm{X} 2$ dilakukan untuk menguji hipotesis statistik kedua dan ketiga yaitu:

1. Hipotesis Kedua

$\mathrm{H}_{0}: \beta_{1} \geq 0$

$\mathrm{H}_{1}: \beta_{1}<0$

2. Hipotesis Ketiga

$\mathrm{H}_{0}: \beta_{2} \geq 0$

$\mathrm{H}_{1}: \beta_{2}<0$

Pengujian hipotesis tersebut dilakukan dengan menggunakan software SPSS 16.0, dengan hasil analisis regresi berganda $\mathrm{Y}$ atas $\mathrm{X} 1$ dan $\mathrm{X} 2$.

Hasil pengolahan data dengan menggunakan software SPSS 16.0, terlihat bahwa Nilai $P_{\text {value }}$ untuk variabel Kreativitas $\left(X_{1}\right)=0,000$ yang berarti signifikan pada $\alpha=$ 0,05 maka untuk hipotesis kedua dinyatakan $\mathrm{H}_{0}$ ditolak, sehingga dapat disimpulkan bahwa variabel kreativitas $\left(X_{1}\right)$ berpengaruh positif secara parsial terhadap variabel prestasi belajar $(\mathrm{Y})$.

Untuk nilai $P_{\text {value }}$ pada variabel persepsi motivasi belajar $\left(X_{2}\right)=0,000$ yang berarti signifikan pada $\alpha=0,05$ maka untuk hipotesis ketiga dinyatakan $\mathrm{H}_{0}$ ditolak, sehingga dapat disimpulkan bahwa variabel motivasi belajar $\left(\mathrm{X}_{2}\right)$ berpengaruh positif secara parsial terhadap variabel prestasi belajar (Y).

\section{Pembahasan Hasil Penelitian}

\section{Pengaruh Kreativitas $\left(X_{1}\right)$ dan Motivasi Belajar $\left(X_{2}\right)$ terhadap Prestasi Belajar $(Y)$}

Hasil pengolahan data dengan menggunakan e SPSS 16.0 sebagaimana yang tersaji pada Tabel 4.8 terlihat bahwa nilai signifikansi $\mathrm{F}_{\text {hit }}\left(\mathrm{P}_{\text {value }}\right)=0,000$ atau lebih besar dari $a=0,05$, sehingga dapat disimpulkan bahwa variabel kreativitas $\left(X_{1}\right)$ dan motivasi belajar $\left(\mathrm{X}_{2}\right)$ secara bersama-sama (simultan) berpengaruh terhadap prestasi belajar (Y). Nilai R Square yang diperoleh $=0,437$. Hal ini menunjukkan bahwa pengaruh variabel kreativitas $\left(X_{1}\right)$ dan motivasi belajar $\left(X_{2}\right)$ terhadap variabel prestasi belajar (Y) adalah sebesar 0,437 atau 43,7\%.

Hasil analisis data tersebut menunjukkan bahwa dalam penelitian ini kreativitas dan motivasi belajar berpengaruh terhadap prestasi belajar yang dalam hal ini adalah siswa Madrasah Aliyah (MA) Al-Badar DDI Parepare. Hal ini sesuai dengan pendapat Supartini bahwa motivasi belajar berpengaruh secara signifikan terhadap hasil belajar atau prestasi belajar siswa. ${ }^{15}$ Demikian pula Sardiman mengemukakan bahwa hal yang mendorong untuk belajar adalah selalu ingin tahu dan adanya keinginan untuk memperbaiki kegagalan di masa lalu dengan usaha yang lebih keras. ${ }^{16}$ 
Pendapat senada juga terlihat dari hasil penelitian Munandar yang menyatakan bahwa kreativitas atau seseorang yang berpikir kreatif adalah orang yang mengembangkan talenta yang dimiliki, belajar menggunakan kemampuan diri sendiri secara optimal, dan melakukan aktivitas-aktivitas baru. ${ }^{17}$

Berdasarkan pendapat tersebut dapat dipahami bahwa peningkatan prestasi belajar dipengaruhi oleh kreativitas dan motivasi belajar

\section{Pengaruh Kreativitas $\left(X_{1}\right)$ terhadap Prestasi Belajar $(Y)$}

Hasil pengolahan data dengan menggunakan SPSS 16.0, terlihat bahwa nilai $P_{\text {value }}$ untuk variabel kreativitas $\left(X_{1}\right)=0,000$ yang berarti signifikan pada $\alpha=0,05$, maka untuk hipotesis kedua dinyatakan $\mathrm{H}_{0}$ ditolak, sehingga dapat disimpulkan bahwa variabel kreativitas $\left(X_{1}\right)$ berpengaruh positif secara parsial terhadap variabel prestasi belajar (Y).

Nilai koefisien regresi untuk variabel kreativitas $\left(\mathrm{X}_{1}\right)$ seperti terlihat pada Tabel 4.7 adalah 0,201 . Hasil ini menunjukkan bahwa setiap peningkatan satu unit variabel kreativitas $\left(\mathrm{X}_{1}\right)$, maka variabel prestasi belajar $(\mathrm{Y})$ mengalami peningkatan sebesar 0,201 kali.

Hasil analisis data tersebut menunjukkan bahwa semakin tinggi kreativitas seorang siswa dalam hal ini adalah siswa Madrasah Aliyah (MA) Al-Badar DDI Parepare Sulawesi Selatan, maka tingkat prestasi belajar siswa mata pelajaran bahasa Arab akan semakin tinggi.

Hasil penelitian ini sesuai dengan pendapat yang disampaikan oleh Utami Munandar yang mengemukakan bahwa kreativitas atau perbuatan kreatif pada umumnya dimiliki oleh orang dengan intelegensi yang cukup tinggi, sehingga peluang memperoleh prestasi tinggi pun semakin besar. Untuk mengembangkan kreativitas siswa dalam pembelajaran, guru perlu menciptakan situasi pembelajaran yang banyak memberi kesempatan kepada siswa untuk memecahkan masalah, melakukan beberapa percobaan, mengembangkan gagasan atau konsep-konsep siswa sendiri. ${ }^{18}$

\section{Pengaruh Persepsi Motivasi Belajar $\left(\mathrm{X}_{2}\right)$ terhadap Prestasi Belajar (Y)}

Hasil pengolahan data dengan menggunakan software SPSS 17.0, terlihat bahwa Nilai $P_{\text {value }}$ untuk variabel motivasi belajar $\left(X_{2}\right)=0,000$ yang berarti signifikan pada $\alpha=0,05$, maka untuk hipotesis ketiga dinyatakan $\mathrm{H}_{0}$ ditolak, sehingga dapat disimpulkan bahwa variabel motivasi belajar $\left(\mathrm{X}_{2}\right)$ berpengaruh positif secara parsial terhadap variabel prestasi belajar (Y).

Nilai koefisien regresi untuk variabel motivasi belajar $\left(X_{2}\right)$ adalah 0,226 . Hasil ini menunjukkan bahwa setiap peningkatan satu unit variabel motivasi belajar $\left(\mathrm{X}_{2}\right)$, maka variabel prestasi belajar (Y) mengalami peningkatan sebesar 0,266 kali.

Hasil analisis data tersebut menunjukkan bahwa semakin tinggi motivasi belajar siswa dalam hal ini Madrasah Aliyah (MA) Al-Badar DDI Parepare Sulawesi Selatan, maka tingkat prestasi belajar siswa pada mata pelajaran bahasa Arab juga semakin tinggi. 
Hasil penelitian ini sesuai dengan pendapat Sardiman bahwa motivasi yang ada dalam diri seseorang memiliki ciri-ciri antara lain tekun menghadapi tugas, ulet menghadapi kesulitan, mempunyai orientasi ke masa depan, dan lebih senang bekerja mandiri. Siswa yang telah termotivasi memiliki keinginan dan harapan untuk berhasil dan mencapai keberhasilan ditunjukkan dalam prestasi belajarnya. Dengan demikian, adanya usaha yang tekun dan terutama didasari adanya motivasi maka seseorang yang belajar akan melahirkan prestasi belajar yang baik. ${ }^{19}$

\section{KESIMPULAN}

Berdasarkan hasil analisa dan pembahasan, maka dapat diambil beberapa kesimpulan sebagai berikut:

1. Terdapat pengaruh yang signifikan secara bersama-sama (simultan) variabel kreativitas $\left(X_{1}\right)$ dan motivasi belajar $\left(X_{2}\right)$ terhadap prestasi belajar siswa $(Y)$. Hal ini berdasarkan hasil analisis data bahwa nilai signifikansi $\mathrm{F}_{\text {hit }}\left(\mathrm{P}_{\text {value }}\right)=0,000$ atau lebih besar dari $a=0,05$. sehingga dapat disimpulkan bahwa kreativitas dan motivasi belajar secara bersama-sama (simultan) berpengaruh terhadap prestasi belajar siswa pada mata pelajaran bahasa Arab di Madrasah Aliyah (MA) Al-Badar DDI Parepare Sulawesi Selatan.

2. Terdapat pengaruh positif variabel kreativitas $\left(X_{1}\right)$ terhadap prestasi belajar $(Y)$. Hal ini berdasarkan hasil analisis data bahwa nilai $P_{\text {value }}$ untuk variabel kreativitas $\left(X_{1}\right)=0,000$ yang berarti signifikan pada $\alpha=0,05$, sehingga dapat disimpulkan bahwa konsep diri berpengaruh positif terhadap prestasi belajar siswa pada mata pelajaran bahasa Arab di Madrasah Aliyah (MA) Al-Badar DDI Parepare Sulawesi Selatan. Nilai koefisien regresi untuk variabel kreativitas $\left(X_{1}\right)$ adalah 0,201 . Hasil ini menunjukkan bahwa setiap peningkatan satu unit variabel kreativitas $\left(X_{1}\right)$, maka variabel prestasi belajar $(Y)$ mengalami peningkatan sebesar 0,201 kali.

3. Terdapat pengaruh positif variabel motivasi belajar $\left(X_{2}\right)$ terhadap prestasi belajar (Y). Hal ini berdasarkan hasil analisis data bahwa nilai $P_{\text {value }}$ untuk variabel motivasi belajar $\left(X_{2}\right)=0,000$ yang berarti signifikan pada $\alpha=0,05$, sehingga dapat disimpulkan bahwa motivasi belajar berpengaruh positif terhadap prestasi belajar siswa pada mata pelajaran bahasa Arab di Madrasah Aliyah (MA) Al-Badar DDI Parepare Sulawesi Selatan. Nilai koefisien regresi untuk variabel motivasi belajar $\left(\mathrm{X}_{2}\right)$ adalah 0,226 . Hasil ini menunjukkan bahwa setiap peningkatan satu unit variabel motivasi belajar $\left(\mathrm{X}_{2}\right)$, maka variabel prestasi belajar $(\mathrm{Y})$ mengalami peningkatan sebesar 0,226 kali.

\section{CATATAN AKHIR:}

1. Hery Noer Aly dan Munzier Suparta, Watak Pendidikan Islam, Jakarta: Friska Agung Insani: 2000, h. 202.

2. Devi Ari Mariani, Peran Belajar Berdasarkan Regulasi Diri dan Gaya Belajar terhadap Prestasi Belajar Matematika Siswa Sekolah Menengah Atas, Tesis, Yogyakarta: FP, UGM, 2007, h. 9. 
3. Eni Handayani, Pengaruh Kreativitas dan Cara Belajar Siswa terhadap Prestasi Belajar Matematika Siswa kelas III SLTP, Skripsi, Yogyakarta: FMIPA, UNY, 2001, hal. 8.

4. M. Ngalim Purwanto, Psikologi Pendidikan, Bandung: PT Remaja Rosdakarya, 2003, h. 84.

5. Slameto, Belajar dan Faktor-faktor yang Mempengaruhinya, Jakarta: PT. Rineka Cipta, 2003, h. 2.

6. Abu Muhammad Ibnu Abdullah, Prestasi Belajar. http://spesialistorch.com/ diakses pada tanggal 12/12/08, h. 2.

7. Muhibbin Syah, Psikologi Belajar, Jakarta: Raja Grafindo Persada, 2006, h. 196.

8. M. Ngalim Purwanto, op.cit., h. 514.

9. Elizabeth B. Hurlock, Perkembangan Anak, Jilid 2 (Meitasari Tjandrasa. Terjemahan). Jakarta:Erlangga, 2002, h. 4,

10. Buchori Alma, Kewirausahaan, Bandung: CV Alfabeta, 2007, h. 70.

11. Hasan Alwi dkk., Kamus Besar Bahasa Indonesia Edisi ketiga, Balai Pustaka: Jakarta, 2002, h. 756 .

12. Nana Syaodih Sukmadinata, Landasan Psikologi Proses Pendidikan, Bandung: PT Remaja Rosdakarya, 2003, h. 61.

13. Nana Syaodih Sukmadinata, ibid., h. 61.

14. Sugiyono, Metode Penelitian Kuantitatif Kualitatif dan RED, Penerbit CV Alfabeta, Bandung, 2010.

15. Eni Handayani, op.cit.

16. AM. Sardiman, Interaksi dan Motivasi Belajar Mengajar, Jakarta: PT Raja Grafindo Persada, 2001.

17. Utami Munandar S.C., Kreativitas dan Keberbakatan, Jakarta: PT. Gramedia Pustaka Utama, 1999, h. 25.

18. Utami Munandar S.C., Mengembangkan Bakat dan kreativitas Anak Sekolah, Jakarta: Gramedia, 1999.

19. AM. Sardiman, Interaksi dan Motivasi Belajar Mengajar, Jakarta: Rajawali Press, 2009, h. 83.

\section{DAFTAR PUSTAKA:}

Abu Muhammad Ibnu Abdullah, Prestasi Belajar. http://spesialistorch.com/ diakses pada tanggal 12/12/08.

Ali, Mohammad, Psikologi Remaja, Jakarta: Bumi Aksara, 2005.

Alma, Buchori, Kewirausahaan, Bandung: CV Alfabeta, 2007.

Alwi, Hasan, dkk., Kamus Besar Bahasa Indonesia Edisi ketiga, Balai Pustaka: Jakarta, 2002.

Aly, Hery Noer dan Munzier Suparta, Watak Pendidikan Islam, Jakarta: Friska Agung Insani: 2000.

Arifin, Zainal, Evaluasi Instruksional, Bandung: Remaja Rosdakarya, 1999.

DePorter, Bobbi \& Mike Hernacki, Quantum Learning, Edisi Revisi, Bandung: Kaifa, 2000.

Gunawan, Adi W., Born to be a Genius, Jakarta: Gramedia Pustaka Utama, 2004.

Hajar, Ibnu, Dasar-dasar Metodologi Penelitian Kualitatif dalam Pendidikan, Jakarta: PT Remaja Rosdakarya, 1999.

Handayani, Eni, Pengaruh Kreativitas dan Cara Belajar Siswa terhadap Prestasi Belajar Matematika Siswa kelas III SLTP, Skripsi, Yogyakarta: FMIPA, UNY, 2001

Hurlock, Elizabeth B., Perkembangan Anak Jilid 2 (Meitasari Tjandrasa. Terjemahan), Jakarta: Erlangga, 2002.

Mariani, Devi Ari, Peran Belajar Berdasarkan Regulasi Diri dan Gaya Belajar terhadap Prestasi Belajar Matematika Siswa Sekolah Menengah Atas, Tesis, Yogyakarta: FP, UGM, 2007. 
Nasution, Berbagai Pendekatan dalam Proses Belajar Mengajar, Cetakan ke-11, Jakarta: Bumi Aksara, 2008.

Ngalim Purwanto, M., Psikologi Pendidikan, Bandung: PT Remaja Rosdakarya, 2003.

Putrawan, I Made Putrawan, Pengujian Hipotesis dalam Penelitian-penelitian Sosial, Jakarta: Rineka Cipta, 1990.

Sardiman, AM., Interaksi dan Motivasi Belajar Mengajar, Jakarta: PT Raja Grafindo Persada, 2001.

Semiawan, Conny R., Perspektif Pendidikan Anak Berbakat, Jakarta: PT. Gramedia Widiasarana Indonesia, 1997

Slameto, Belajar dan Faktor-faktor yang Mempengaruhinya, Jakarta: PT. Rineka Cipta, 2003.

Slameto, Manajemen Penelitian, Rineka Cipta: Jakarta, 2002.

Slameto, Prosedur Penelitian: Suatu Pendekatan Praktik, Rineka Cipta: Jakarta, 2006.

Sugiyono, Metode Penelitian Kuantitatif Kualitatif dan RED, Penerbit CV Alfabeta, Bandung, 2010.

Sukmadinata, Nana Syaodih, Landasan Psikologi Proses Pendidikan, Bandung: PT Remaja Rosdakarya, 2003.

Supriyadi, Dedi, Kreativitas, Kebudayaan, dan Perkembangan Iptek, Bandung: CV Alfabeta, 1997.

Suryabrata, S., Psikologi pendidikan, Jakarta: Fajar Interpratama Offset, 2002.

Syah, Muhibbin Syah, Psikologi Belajar, Jakarta: Raja Grafindo Persada, 2006.

Tohirin, Psikologi Pembelajaran Pendidikan Agama Islam, Jakarta: Raja Grafindo Persada, 2006.

Uno, Hamzah B., dkk., Landasan Pembelajaran, Gorontalo: Nurul Jannah, 2004.

Utami Munandar S.C., Kreativitas dan Keberbakatan, Jakarta: PT. Gramedia Pustaka Utama, 1999.

Utami Munandar S.C., Mengembangkan Bakat dan kreativitas Anak Sekolah, Jakarta: Gramedia, 1999.

Winkel, W.S., Psikologi Pengajaran, Edisi Revisi, Jakarta: Raja Grasindo Persada, 1999. 